\title{
Nitrogen rate and plant density interaction enhances grain yield by regulating the grain distribution of secondary branches on the panicle axis and photosynthesis in japonica rice
}

\author{
Y.L. GONG ${ }^{* * *}$, Y. LEI**, X.P. ZHANG*, B.C. YAN*, X.T. JU*, X.Y. CHENG*, J.D. ZHANG*, X.Y. SUN*, \\ H. XU*,+, and W.F. CHEN",+ \\ College of Agronomy, Rice Research Institute, Shenyang Agricultural University, 110866 Shenyang, Liaoning \\ Province, China* \\ Guizhou Rice Research Institute, Guizhou Academy of Agricultural Sciences, 550006 Guiyang, China**
}

\begin{abstract}
Two japonica rice cultivars with different panicle trait index (PTI), HP917 (a high-PTI cultivar) and DP128 (a lowPTI cultivar) were used to investigate the effects of the nitrogen $(\mathrm{N})$ rate and plant density on the grain distribution of secondary branches on the panicle axis, leaf photosynthetic characteristics, and grain yield by a split plot design. The main plots were assigned to four $\mathrm{N}$ rates $\left(0,140,200\right.$, and $\left.260 \mathrm{~kg} \mathrm{ha}^{-1}\right)$, and the subplots were assigned to two plant densities: $\left(\mathrm{D}_{20}, 15\right.$ plants $\mathrm{m}^{-2} ; \mathrm{D}_{10}, 30$ plants $\left.\mathrm{m}^{-2}\right)$. Results showed that the grain yield was increased by increasing $\mathrm{N}$ rate and plant density, reaching a peak at $\mathrm{N}_{200}$ with $\mathrm{D}_{10}$. Compared with $\mathrm{N}_{0}$ treatment, the PTIs of HP917 and DP128 increased with an increase in the N rate, respectively. The PTIs of HP917 and DP128 increased by $4 \%$ with increasing plant density from $\mathrm{D}_{20}$ to $\mathrm{D}_{10}$. The leaf capacity was significantly affected by $\mathrm{N}$ rate and plant density. The grain distribution characteristics of secondary branches on the panicle axis was closely related to yield. Correlation analysis showed the PTI was positively correlated with grain yield and net photosynthetic rate. These results suggested the improvement in PTI from 0.15 to 0.52 was beneficial to increase the grain yield, which might contribute to the increased grain number of secondary branches of the middle and bottom panicle.
\end{abstract}

Keywords: grain; panicle trait index; photosynthetic characteristics; secondary branches.

\section{Introduction}

Rice (Oryza sativa L.) is a staple food for more than $50 \%$ of the global population, and it plays a key role in maintaining food security (Fitzgerald et al. 2009, Zhao et al. 2009, Muthayya et al. 2014, Veronica et al. 2017). Predicted results show that 116 million additional tons of rice will be needed by 2035 (Seck et al. 2012, Yamano

\section{Highlights}

- Nitrogen rate and plant density interaction improved the grain number of secondary branches of japonica rice

- The improvement in panicle trait index (PTI) enhanced the grain yield

- The improvement in PTI improved the net photosynthetic rate
Received 21 October 2021

Accepted 12 January 2022

Published online 31 January 2022

${ }^{+}$Corresponding authors

e-mail: chinaxuhai@163.com (H.Xu) wfchen@syau.edu.cn (W.F. Chen)

Abbreviations: BFSB - filled grain number of secondary branches of the bottom panicle; BSB - grain number of secondary branches of the bottom panicle; $\mathrm{Chl}$ - chlorophyll; $C_{\mathrm{i}}$ - intercellular $\mathrm{CO}_{2}$ concentration; $E$ - transpiration rate; $\mathrm{F}$ - filled grain rate; FGNSB filled grain number of secondary branches; GNPB - grain number of primary branches; GNSB - grain number of secondary branches; GPP - grain number per panicle; $g_{s}-$ stomatal conductance; $L_{s}-$ stomatal limitation value; MFSB - filled grain number of secondary branches of the middle panicle; MSB - grain number of secondary branches of the middle panicle; $\mathrm{P}$ - total panicle number per hectare; $P_{\mathrm{N}}$ - net photosynthetic rate; PTI - panicle trait index; SSRSB - seed-setting rate of secondary rachis branches; TFSB - filled grain number of secondary branches of the top panicle; TSB - grain number of secondary branches of the top panicle; $\mathrm{W}$ - 1,000-grain mass; $\mathrm{Y}$ - grain yield.

Acknowledgments: We are grateful for grants from the National Modern Agriculture Industry Technology System (CARS-01-12) and the Youth Science and Technology Fund of Guizhou Academy of Agricultural Sciences (2021-13).

Conflict of interest: The authors declare that they have no conflict of interest. 
et al. 2016). However, with increasing population pressure and expanding urbanization, stable crop production is being threatened (Liu et al. 2016). Thus, there is an urgent requirement to increase rice production to meet the continuous demand of food supply (Wang et al. 2015).

Rice yield is determined by its components, such as panicle number per hectare $(\mathrm{P})$, grain number per panicle (GPP), and thousand-grain mass (W) (Hua et al. 2002). Most studies have proven that maintaining or reducing $\mathrm{P}$ and increasing GPP are the main ways to increase rice yield (Hua et al. 2002, Kato et al. 2007). As a result, large panicles bearing numerous grain numbers of rice varieties such as 'super' rice or 'super' hybrid rice in China have been successfully developed (Peng et al. 2008, Yang and Zhang 2010). However, an excess of the bottom grain number of secondary branches (GNSB) and poor filling are the major factors limiting the high grain yield potential of these varieties (Sekhar et al. 2015). Optimization of the GNSB on the panicle axis is required to improve the yield potential. Sasahara et al. (1982) showed that the grain distribution of secondary branches on the panicle axis was mainly controlled by heredity and was closely related to yield. The ratio of the number of primary branches to the node position of the axis where the primary branch with the largest grain number of secondary branches was taken as an indicator of the 'Sasahara index' and has shown that indica rice is a superior dominant type, japonica rice is a middle dominant type, and javanica rice is an inferior dominant type (Sasahara et al. 1982). To accurately reflect the grain distribution characteristics of secondary branches on the panicle axis, Xu et al. (2005) proposed the PTI is the ratio between the number of axis internodes and the number of grains in secondary rachis branches higher than those in primary rachis branches, and the number of primary rachis branches reflects the distribution characteristics of the GNSB on the panicle axis and they reported that a high PTI is advantageous for increasing yield. However, there are few published studies in this field. Thus, it is necessary to further study whether this trend could be found in the improved cultivars.

$\mathrm{N}$ application and plant density are the two most important crop management practices that significantly affect grain yield by regulating yield components, photosynthesis, and growth (Berry et al. 2010, Sun et al. 2012, Mu et al. 2016, Di Salvo et al. 2018). Previous studies have revealed that $\mathrm{N}$ deficiency leads to a significant decline in GPP (Jin and He 1999) and a positive correlation between grain number per unit area and spikelet $\mathrm{N}$ content (Fischer 2011). Plant density is an important determinant of the number of grains per plant. Most studies have shown a strong positive relationship between GPP and tiller dry mass at the heading stage (Yao et al. 2000, Shiratsuchi et al. 2007). In addition, a negative relationship between GPP and panicle number has been widely reported (Wells and Faw 1978, Jones and Snyder 1987). Therefore, the difference in the numbers of panicles and tillers caused by different plant densities might also affect the GPP (Kuroda et al. 1999). However, few studies have paid attention to the effects of the $\mathrm{N}$ rate and plant density interaction on the PTI.
Photosynthesis is an integral part of crop yield. Previous studies have shown a reduction in the photosynthetic rate $\left(P_{\mathrm{N}}\right)$ under nitrogen-deficient conditions (Jin and $\mathrm{He}$ 1999, Shangguan et al. 2000). N fertilization increases the chlorophyll $(\mathrm{Chl})$ content and improves $P_{\mathrm{N}}$ and the leaf area (Li et al. 2012). Photosynthesis and leaf area per tiller are the main factors affecting the source ability for panicle development (Sheehy et al. 2001). In addition, a lack of $\mathrm{N}$ reduces the radiation-use efficiency, Chl content, and protein content of the plant (Steer and Harrigan 1986, Dordas and Sioulas 2008). The photosynthetic capacity of leaves was shown to be positively correlated with the $\mathrm{N}$ application rate (Sage and Pearcy 1987).

Numerous previous studies have focused on the effect of the $\mathrm{N}$ rate and plant density on the yield and components (Fang et al. 2018, Hou et al. 2019). However, the effect of the $\mathrm{N}$ rate and plant density interaction on PTI is unclear. Thus, this study aimed to (1) investigate the effects of the $\mathrm{N}$ rate and plant density on the PTI, leaf photosynthetic characteristics, and grain yield of rice plants with different PTIs and (2) explore whether the $\mathrm{N}$ rate and plant density interaction enhance grain yield by regulating the PTI of japonica rice. These results might provide a scientific basis for the production of high grain yield by improving the PTI in low-PTI rice.

\section{Materials and methods}

Plant material and experimental design: A field experiment was conducted at the Rice Research Institute of Shenyang Agricultural University, Shenyang, China $\left(41^{\circ} 48^{\prime} \mathrm{N}, 123^{\circ} 34^{\prime} \mathrm{E}\right)$. The soil properties in the $0-20-\mathrm{cm}$ deep soil layer of the experimental field were as follows: pH 6.2; $26.3 \mathrm{~g}$ (organic matter content) $\mathrm{kg}^{-1} ; 0.87 \mathrm{~g}$ (total N) $\mathrm{kg}^{-1} ; 1.1 \mathrm{~g}$ (total P) $\mathrm{kg}^{-1} ; 8.93 \mathrm{~g}$ (total K) $\mathrm{kg}^{-1} ; 100.3$ $\mathrm{mg}($ available $\mathrm{N}) \mathrm{kg}^{-1}$; $61.3 \mathrm{mg}$ (available $\left.\mathrm{P}\right) \mathrm{kg}^{-1}$; and $113.59 \mathrm{mg}$ (available K) $\mathrm{kg}^{-1}$. We screened japonica rice cultivars in 2019, and a comprehensive evaluation of agronomic characteristics showed that the HP917 cultivar is a high-PTI cultivar $(\mathrm{PTI}=0.46)$ and that DP128 is a low-PTI cultivar (PTI $=0.15)$ (Fig. 1$)$. These two cultivars were used as the experimental material in this study.

The experiment was conducted with a split-split plot design with the two japonica rice cultivars with different PTIs as the main plots; cultivars with four $\mathrm{N}$ concentrations of $0 \mathrm{~kg}(\mathrm{~N}) \mathrm{ha}^{-1}\left(\mathrm{~N}_{0}\right), 140 \mathrm{~kg}(\mathrm{~N}) \mathrm{ha}^{-1}\left(\mathrm{~N}_{140}\right)$, $200 \mathrm{~kg}(\mathrm{~N}) \mathrm{ha}^{-1}\left(\mathrm{~N}_{200}\right)$, and $260 \mathrm{~kg}(\mathrm{~N}) \mathrm{ha}^{-1}\left(\mathrm{~N}_{260}\right)$ as the split plots; and two cultivars with plant densities of 30 plants $\mathrm{m}^{-2}$, representing a high density $\left(\mathrm{D}_{10}\right)$, and 15 plants $\mathrm{m}^{-2}$, representing a low density $\left(\mathrm{D}_{20}\right)$, as sub-split plots. All treatments were conducted in triplicate. The size of each main plot was $48.72 \mathrm{~m}^{2}$ (5.8 $\mathrm{m}$ long, $8.4 \mathrm{~m}$ wide, 28 rows, $30-\mathrm{cm}$ row spacing), and the size of each split plot was $24.375 \mathrm{~m}^{2}$ (5.8 m long, $4.2 \mathrm{~m}$ wide, 14 rows, $30-\mathrm{cm}$ row spacing). Each plot was separated by $0.4 \mathrm{~m}$ wide ridges covered with plastic film to restrain leakage and nutrient loss. The rice seeds were sown on 16 April 2020 and were transplanted at the 3.5-leaf stage, rice harvest on the 22-26 September. Each hill had two seedlings in all plots. Each plot was regularly hand-weeded, and pesticides were 


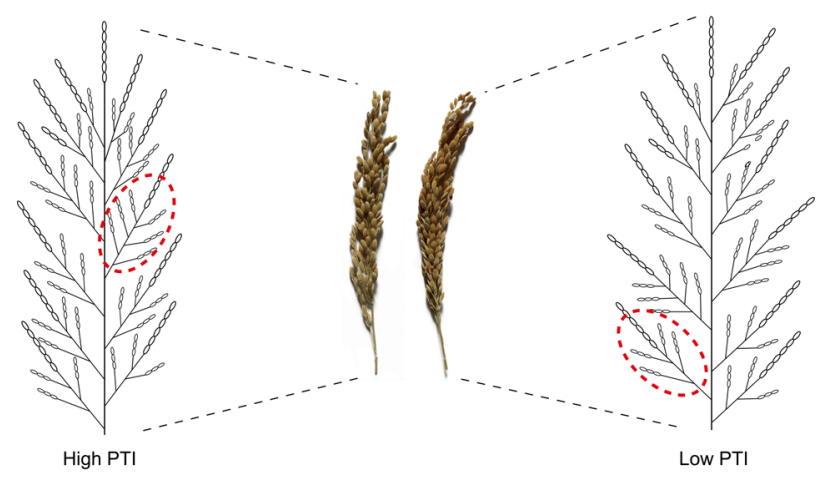

Fig. 1. Largest secondary branch grain number of primary branches on the node of the panicle axis in different panicle trait index (PTI) rice lines.

used to prevent pest and insect damage. Nitrogen $(\mathrm{N})$, potassium $\left(\mathrm{K}_{2} \mathrm{O}\right)$, and phosphorus $\left(\mathrm{P}_{2} \mathrm{O}_{5}\right)$ were applied as urea $(46 \% \mathrm{~N})$, potassium chloride $\left(60 \% \mathrm{~K}_{2} \mathrm{O}\right)$, and calcium superphosphate $\left(12 \% \mathrm{P}_{2} \mathrm{O}_{5}\right)$, respectively. $\mathrm{K}_{2} \mathrm{O}$ and $\mathrm{P}_{2} \mathrm{O}_{5}$ were both applied at a rate of $90 \mathrm{~kg} \mathrm{ha}^{-1}$. Fifty percent of $\mathrm{N}, 60 \%$ of $\mathrm{K}_{2} \mathrm{O}$, and all of $\mathrm{P}_{2} \mathrm{O}_{5}$ were applied basally before transplantation, followed by $25 \%$ of $\mathrm{N}$ and $20 \%$ of $\mathrm{K}_{2} \mathrm{O}$ applied at the tillering stage, and the remaining $25 \%$ of $\mathrm{N}$ and $20 \%$ of $\mathrm{K}_{2} \mathrm{O}$ were applied at the booting stage. Field management was conducted during the entire growing season by following local practices.

Panicle traits: At maturity, ten plants from the center of each plot were sampled to investigate the number of primary branches of all panicles. Among them, ten panicles were taken according to the mode. Each panicle was divided into three parts, top, middle, and bottom, according to primary branches. The grain number of primary branches (GNPB), GNSB, and $\mathrm{W}$ values of the primary and secondary branches were measured. The filled grain rate $(\mathrm{F})$ of primary and secondary branches was calculated using the following equation: $\mathrm{F}=$ (filled GPP/ number of grains per panicle) $\times 100 \%$.

Panicle trait index: At maturity, ten plants from the center of each plot were sampled to investigate the number of primary branches of all panicles. Among them, ten panicles were taken according to the mode, and the primary branches were numbered from bottom to top on the panicle axis. The secondary branch GNPB was measured, and the PTI was calculated using the following equation: PTI = the largest secondary branch GNPB on the node of the panicle axis/number of primary branches.

The photosynthetic pigment content was measured by following the method proposed by Lichtenthaler (1987). Samples $(0.1 \mathrm{~g})$ of fresh leaves, excluding main veins, were immersed in ethanol $(95 \%, \mathrm{v} / \mathrm{v})$ and kept at $4{ }^{\circ} \mathrm{C}$ in the dark for $2 \mathrm{~d}$ until the leaf became white. The absorbance of the extract was read at 665,649 , and $470 \mathrm{~nm}$ using a spectrophotometer (1510, Thermo Fisher, USA). The contents of $\mathrm{Chl}$ and carotenoids were calculated using the following equations: $\mathrm{Chl} a\left[\mathrm{mg} \mathrm{g}^{-1}(\mathrm{FM})\right]=\left(13.95 \mathrm{~A}_{665}-\right.$ $\left.6.88 \mathrm{~A}_{649}\right) \times \mathrm{V} /(1,000 \times \mathrm{M})$, Chl $b\left[\mathrm{mg} \mathrm{g}^{-1}(\mathrm{FM})\right]=$ $\left(24.96 \mathrm{~A}_{649}-7.32 \mathrm{~A}_{665}\right) \times \mathrm{V} /(1,000 \times \mathrm{M}), \mathrm{Chl}(a+b)[\mathrm{mg}$ $\left.\mathrm{g}^{-1}(\mathrm{FM})\right]=\mathrm{Chl} a+\mathrm{Chl} b$, where $\mathrm{A}_{665}, \mathrm{~A}_{649}$, and $\mathrm{A}_{470}$ are absorbances at 665,649 , and $470 \mathrm{~nm}$, respectively; $\mathrm{V}$ is the total volume of the extract $(10 \mathrm{ml}) ; \mathrm{M}$ is the mass of the sample $(0.1 \mathrm{~g})$.

Gas-exchange measurement: The flag leaf gas exchange was measured using a portable infrared gas analyzer (CIRAS 3, PP Systems) at the heading stage. $P_{\mathrm{N}}$, the transpiration rate $(E)$, the stomatal conductance $\left(g_{\mathrm{s}}\right)$, and the intercellular $\mathrm{CO}_{2}$ concentration $\left(C_{\mathrm{i}}\right)$ were recorded at PPFD of $1,200 \mu \mathrm{mol} \mathrm{m}{ }^{-2} \mathrm{~s}^{-1}$ from an internal light source in the leaf chamber in which the relative humidity was $60 \%$, the $\mathrm{CO}_{2}$ concentration was $400 \mu \mathrm{mol} \mathrm{mol}^{-1}$, and the leaf temperature was $25^{\circ} \mathrm{C}$. The stomatal limitation value $\left(\mathrm{L}_{\mathrm{s}}\right)$ was calculated as $1-C_{\mathrm{i}} / C_{\mathrm{a}}$ (Fang et al. 2018). All parameters were measured on six individual plants per treatment between 10:00 and 11:00 h (Zhang et al. 2019).

Yield and yield components: For each plot, three 2- $\mathrm{m}^{2}$ areas were harvested to measure grain yield. The panicle number per ha was determined by counting the panicle number per plant and multiplying it by the plant density.

Statistical analysis: Data from each of the treatments were subjected to analysis of variance (ANOVA) using SPSS 22.0 software (IBM Inc.). The data were first checked for normality (Kolmogorov-Smirnov test) and homogeneity of variance (Bartlett-Box test). The data had a normal distribution and homogeneous variance. The means were tested by the least significant difference $(L S D)$ test at the 0.05 level of significance. Graphs were generated using Origin 2018 software. The data in graphs are expressed as the mean \pm standard deviation.

\section{Results}

Grain yield and yield components: N rate, plant density, and their interaction had significant effects on the grain yield of rice plants with different PTIs (Table 1). With increasing $\mathrm{N}$ rate, the grain yield of rice significantly increased at first and then decreased in HP917 and DP128 (mean of two plant densities). Compared with $\mathrm{N}_{0}$, the grain yields of HP917 and DP128 steadily increased by 2.47 and $2.34 \mathrm{t} \mathrm{ha}^{-1}$, with the rate of increase of 37.8 and $36.5 \%$, respectively. Compared to the low-plant density $\left(D_{20}\right)$ rice, the grain yields of HP917 and DP128 increased by 1.4 and $2.04 \mathrm{tha}^{-1}$, with the rate of increase of 4.1 and $6.3 \%$ achieved under high-planting density $\left(\mathrm{D}_{10}\right)$ conditions, respectively. $\mathrm{N}_{200}$ combined with $\mathrm{D}_{10}$ was optimal for yield formation for all the treatments in both HP917 and DP128.

According to $A N O V A$ results, $\mathrm{N}$ rate and plant density, not $\mathrm{W}$, had significant effects on GPP, P, and F, and their interaction had significant effects on P and GPP in HP917 and DP128 (Table 1). With increasing N rate, GPP and P significantly increased, but $\mathrm{F}$ significantly decreased in HP917 and DP128. Increasing the plant density from $D_{20}$ to $\mathrm{D}_{10}$ significantly decreased the GPP values of HP917 and 
Table 1. Effect of the $\mathrm{N}$ rate and plant density on the grain yield and yield components in rice with different PTIs. $\mathrm{N}_{0}-0 \mathrm{~kg}(\mathrm{~N})$ ha ${ }^{-1}$; $\mathrm{N}_{140}-140 \mathrm{~kg}(\mathrm{~N})$ ha $^{-1} ; \mathrm{N}_{200}-200 \mathrm{~kg}(\mathrm{~N}) \mathrm{ha}^{-1} ;$ and $\mathrm{N}_{260}-260 \mathrm{~kg}(\mathrm{~N})$ ha ${ }^{-1}$. D represents the plant density, where $\mathrm{D}_{20}$ represents 15 plants $\mathrm{m}^{-2}$ and $\mathrm{D}_{10}$ represents 30 plants $\mathrm{m}^{-2}$. P represents the panicle number per hectare, GPP represents the grain number per panicle, F represents the filled grain rate, and W represents the 1,000-grain mass. Data are represented as the mean \pm SD of triplicates. $*$ and $* *$ indicate that the $\mathrm{N}$ rate and planting density and their interactions significantly influenced the yield components at the 0.05 and 0.01 levels, respectively, and ns indicates 'nonsignificant'. Values of eight treatments followed by different lowercase letters indicate a significant difference at the $5 \%$ level.

\begin{tabular}{|c|c|c|c|c|c|c|c|}
\hline \multirow{2}{*}{$\frac{\text { Variety }}{\text { HP917 }}$} & \multicolumn{2}{|c|}{ Treatments } & \multirow{2}{*}{$\frac{Y\left[\mathrm{tha}^{-1}\right]}{6.33 \pm 0.11^{\mathrm{f}}}$} & \multirow{2}{*}{$\frac{\mathrm{P}\left[\times 10 \mathrm{ha}^{-1}\right]}{125.5 \pm 12.4^{\mathrm{h}}}$} & \multirow{2}{*}{$\frac{\text { GPP }}{185.7 \pm 0.6^{\mathrm{e}}}$} & \multirow{2}{*}{$\frac{\mathrm{F}[\%]}{91.0 \pm 1.4^{\mathrm{b}}}$} & \multirow{2}{*}{$\frac{\mathrm{W}[\mathrm{g}]}{29.13 \pm 0.32^{\mathrm{a}}}$} \\
\hline & $\mathrm{N}_{0}$ & $\mathrm{D}_{20}$ & & & & & \\
\hline & & $\mathrm{D}_{10}$ & $6.75 \pm 0.25^{\mathrm{e}}$ & $160.1 \pm 16.2^{\mathrm{g}}$ & $163.3 \pm 2.1^{\mathrm{f}}$ & $94.0 \pm 0.6^{\mathrm{a}}$ & $28.42 \pm 0.41^{\mathrm{ab}}$ \\
\hline & $\mathrm{N}_{140}$ & $\mathrm{D}_{20}$ & $7.89 \pm 0.11^{\mathrm{d}}$ & $170.9 \pm 22.0^{\mathrm{f}}$ & $222.7 \pm 3.2^{\mathrm{c}}$ & $85.0 \pm 0.7^{\mathrm{d}}$ & $28.01 \pm 0.58^{\mathrm{ab}}$ \\
\hline & & $\mathrm{D}_{10}$ & $8.13 \pm 0.03^{c}$ & $222.1 \pm 34.6^{\mathrm{c}}$ & $200.3 \pm 5.5^{\mathrm{d}}$ & $88.0 \pm 0.6^{c}$ & $27.98 \pm 0.48^{\mathrm{ab}}$ \\
\hline & $\mathrm{N}_{200}$ & $\mathrm{D}_{20}$ & $10.20 \pm 0.14^{\mathrm{a}}$ & $211.6 \pm 16.3^{\mathrm{e}}$ & $241.3 \pm 2.3^{\mathrm{a}}$ & $84.0 \pm 0.4^{\mathrm{d}}$ & $27.80 \pm 0.43^{\mathrm{ab}}$ \\
\hline & & $\mathrm{D}_{10}$ & $10.30 \pm 0.03^{\mathrm{a}}$ & $246.4 \pm 34.1^{\mathrm{b}}$ & $222.0 \pm 2.2^{\mathrm{c}}$ & $87.0 \pm 1.4^{\mathrm{c}}$ & $27.74 \pm 0.41^{\mathrm{ab}}$ \\
\hline & $\mathrm{N}_{260}$ & $\mathrm{D}_{20}$ & $9.59 \pm 0.14^{b}$ & $219.6 \pm 15.0^{\mathrm{d}}$ & $231.0 \pm 1.2^{\mathrm{b}}$ & $76.0 \pm 2.1^{\mathrm{f}}$ & $27.39 \pm 0.25^{b}$ \\
\hline & & $\mathrm{D}_{10}$ & $10.20 \pm 0.02^{\mathrm{a}}$ & $255.2 \pm 32.2^{\mathrm{a}}$ & $218.0 \pm 2.1^{\mathrm{c}}$ & $82.0 \pm 1.5^{\mathrm{e}}$ & $27.29 \pm 0.26^{b}$ \\
\hline \multirow[t]{8}{*}{ DP128 } & $\mathrm{N}_{0}$ & $\mathrm{D}_{20}$ & $6.15 \pm 0.34^{\mathrm{h}}$ & $129.3 \pm 15.1^{\mathrm{h}}$ & $221.0 \pm 3.0^{\mathrm{f}}$ & $76.7 \pm 1.0^{c}$ & $25.66 \pm 0.45^{\mathrm{a}}$ \\
\hline & & $\mathrm{D}_{10}$ & $6.66 \pm 0.20^{\mathrm{g}}$ & $178.1 \pm 16.2^{\mathrm{e}}$ & $208.0 \pm 4.9^{\mathrm{g}}$ & $83.0 \pm 2.3^{\mathrm{a}}$ & $25.60 \pm 0.56^{\mathrm{a}}$ \\
\hline & $\mathrm{N}_{140}$ & $\mathrm{D}_{20}$ & $7.17 \pm 0.06^{\mathrm{f}}$ & $156.4 \pm 12.1^{\mathrm{g}}$ & $235.1 \pm 4.0^{\mathrm{e}}$ & $74.7 \pm 1.1^{\mathrm{d}}$ & $25.45 \pm 0.89^{\mathrm{a}}$ \\
\hline & & $\mathrm{D}_{10}$ & $7.45 \pm 0.17^{\mathrm{e}}$ & $200.4 \pm 21.2^{\mathrm{f}}$ & $212.0 \pm 2.0^{\mathrm{g}}$ & $80.0 \pm 1.0^{\mathrm{b}}$ & $25.20 \pm 0.26^{\mathrm{a}}$ \\
\hline & $\mathrm{N}_{200}$ & $\mathrm{D}_{20}$ & $9.65 \pm 0.13^{\mathrm{c}}$ & $169.1 \pm 15.3^{\mathrm{f}}$ & $276.0 \pm 1.7^{\mathrm{a}}$ & $65.3 \pm 3.2^{\mathrm{e}}$ & $25.04 \pm 0.70^{\mathrm{a}}$ \\
\hline & & $\mathrm{D}_{10}$ & $10.20 \pm 0.06^{\mathrm{a}}$ & $216.1 \pm 20.0^{\mathrm{b}}$ & $252.0 \pm 1.7^{\mathrm{c}}$ & $75.0 \pm 1.8^{\mathrm{d}}$ & $25.01 \pm 0.56^{\mathrm{a}}$ \\
\hline & $\mathrm{N}_{260}$ & $\mathrm{D}_{20}$ & $9.19 \pm 0.17^{\mathrm{d}}$ & $180.6 \pm 13.3^{\mathrm{d}}$ & $260.0 \pm 1.2^{\mathrm{b}}$ & $63.0 \pm 2.2^{\mathrm{f}}$ & $25.04 \pm 0.37^{\mathrm{a}}$ \\
\hline & & $\mathrm{D}_{10}$ & $9.90 \pm 0.28^{\mathrm{b}}$ & $235.1 \pm 22.4^{\mathrm{a}}$ & $245.3 \pm 1.2^{\mathrm{d}}$ & $65.0 \pm 0.6^{\mathrm{e}}$ & $24.02 \pm 0.44^{b}$ \\
\hline \multirow[t]{7}{*}{$A N O V A$} & \multicolumn{2}{|c|}{ N level (N) } & $* *$ & $* *$ & $* *$ & $* *$ & $* *$ \\
\hline & \multicolumn{2}{|c|}{ Density (D) } & $* *$ & $* *$ & $* *$ & $* *$ & ns \\
\hline & \multicolumn{2}{|c|}{ Variety (V) } & $*$ & $* *$ & $* *$ & $* *$ & $*$ \\
\hline & \multicolumn{2}{|c|}{$\mathrm{V} \times \mathrm{N}$} & $*$ & $* *$ & $* *$ & $* *$ & ns \\
\hline & \multicolumn{2}{|c|}{$\mathrm{V} \times \mathrm{D}$} & $\mathrm{ns}$ & $* *$ & ns & $* *$ & ns \\
\hline & \multicolumn{2}{|c|}{$\mathrm{N} \times \mathrm{D}$} & $*$ & $* *$ & $* *$ & $\mathrm{~ns}$ & ns \\
\hline & \multicolumn{2}{|c|}{$\mathrm{V} \times \mathrm{N} \times \mathrm{D}$} & ns & $* *$ & $\mathrm{~ns}$ & ns & $\mathrm{ns}$ \\
\hline
\end{tabular}

DP128 by 8.7 and $7.5 \%$ (mean of four $\mathrm{N}$ rates), respectively. The P of HP917 and DP128 significantly increased by 17.6 and $23.4 \%$ (mean of four $\mathrm{N}$ rates), respectively. The $\mathrm{F}$ of HP917 and DP128 significantly increased by 4.2 and $7.7 \%$ (mean of four $\mathrm{N}$ rates), respectively. However, $\mathrm{N}$ rate and plant density had similar effects on W for both HP917 and DP128 and decreased with increasing $\mathrm{N}$ rate and plant density.

Panicle trait: $\mathrm{N}$ rate, plant density, and their interaction had significant effects on the GNPB, the filled grain number of secondary branches (FGNSB) of the middle and bottom panicle, the GNSB of the middle and bottom panicles, and the seed-setting rate of secondary branches (SSRSB) of the middle and bottom panicle, but no significant effect on the FGNSB, GNSB, and SSRSB of the top panicle was observed in HP917 and DP128 (Table 2). With an increase in the $\mathrm{N}$ rate, the FGNSB and GNSB of the middle and bottom panicles significantly increased at first and then decreased at both plant densities in HP917 and DP128. The GNPB increased with the increasing $\mathrm{N}$ rate, but it decreased with the increasing plant density. However, the effects of the $\mathrm{N}$ rate and the plant density on the SSRSB of the middle and bottom panicles were similar in HP917 and DP128, and both values decreased with increasing $\mathrm{N}$ application rate and the plant density.

Panicle trait index: The grain distribution of secondary branches on the panicle axis was closely related to yield. The $\mathrm{N}$ rate and plant density interaction increased the number of primary branches and the GNSB of the middle and bottom panicles, which, in turn, influenced the PTI (Figs. 2 and 3). Compared with $\mathrm{N}_{0}$ treatment, $\mathrm{N}_{140}$ treatment increased the number of primary branches of HP917 and DP128 in the $\mathrm{D}_{20}$ group and affected the PTI of other groups by moving up the largest secondary branch GNPB on the node of the panicle axis of HP917 and DP128.

$\mathrm{N}$ rate, plant density, and their interaction significantly affected the PTI of HP917 and DP128, as shown in Fig. 3. As the $\mathrm{N}$ rate increased from $0 \mathrm{~kg} \mathrm{ha}^{21}$ to $200 \mathrm{~kg} \mathrm{ha}^{-1}$, the PTIs of HP917 and DP128 increased from 0.46 and 0.15 to 0.52 and 0.30 (mean of two plant densities), respectively. However, as the $\mathrm{N}$ rate increased from $200 \mathrm{~kg} \mathrm{ha}^{-1}$ to 


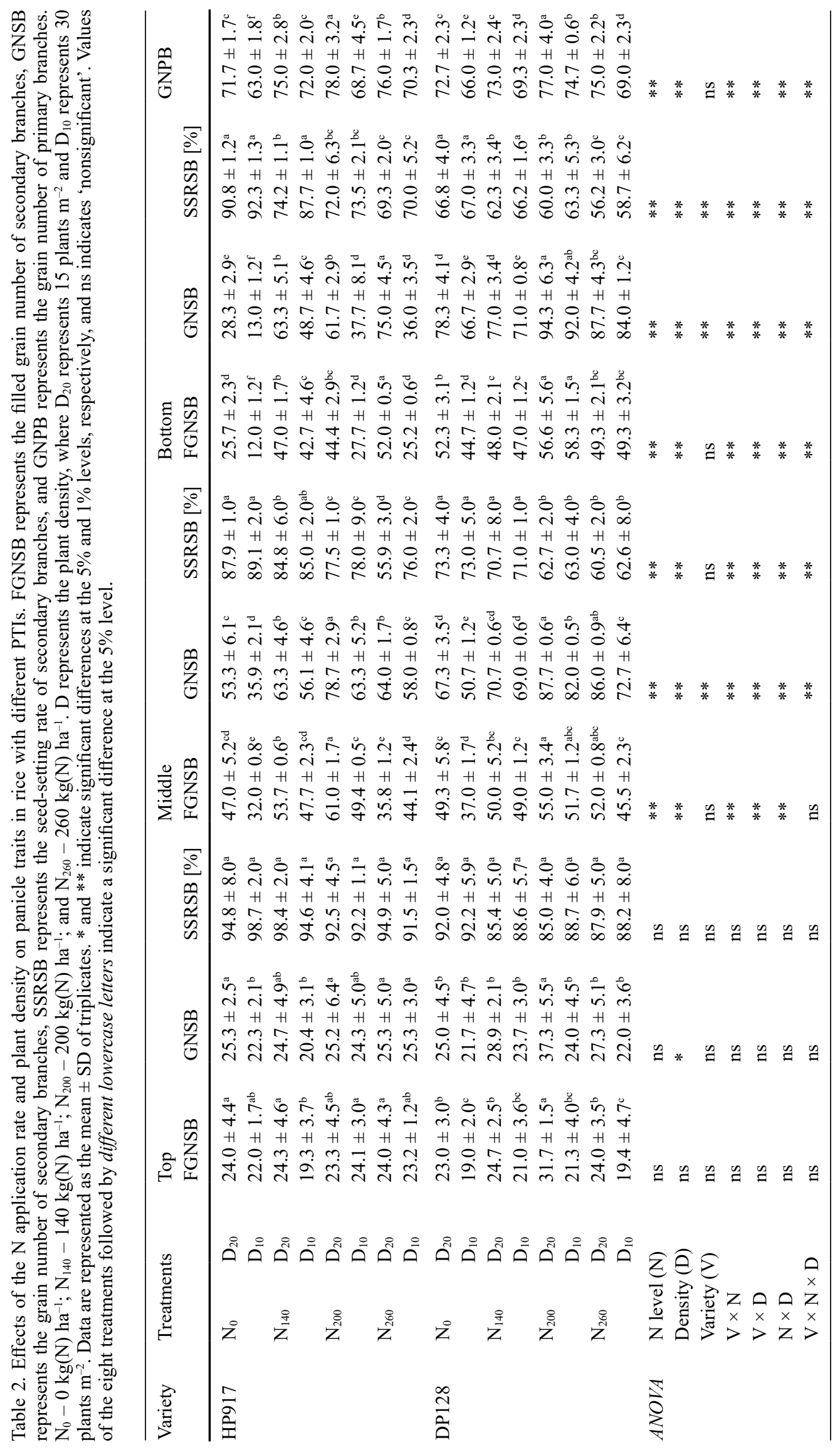




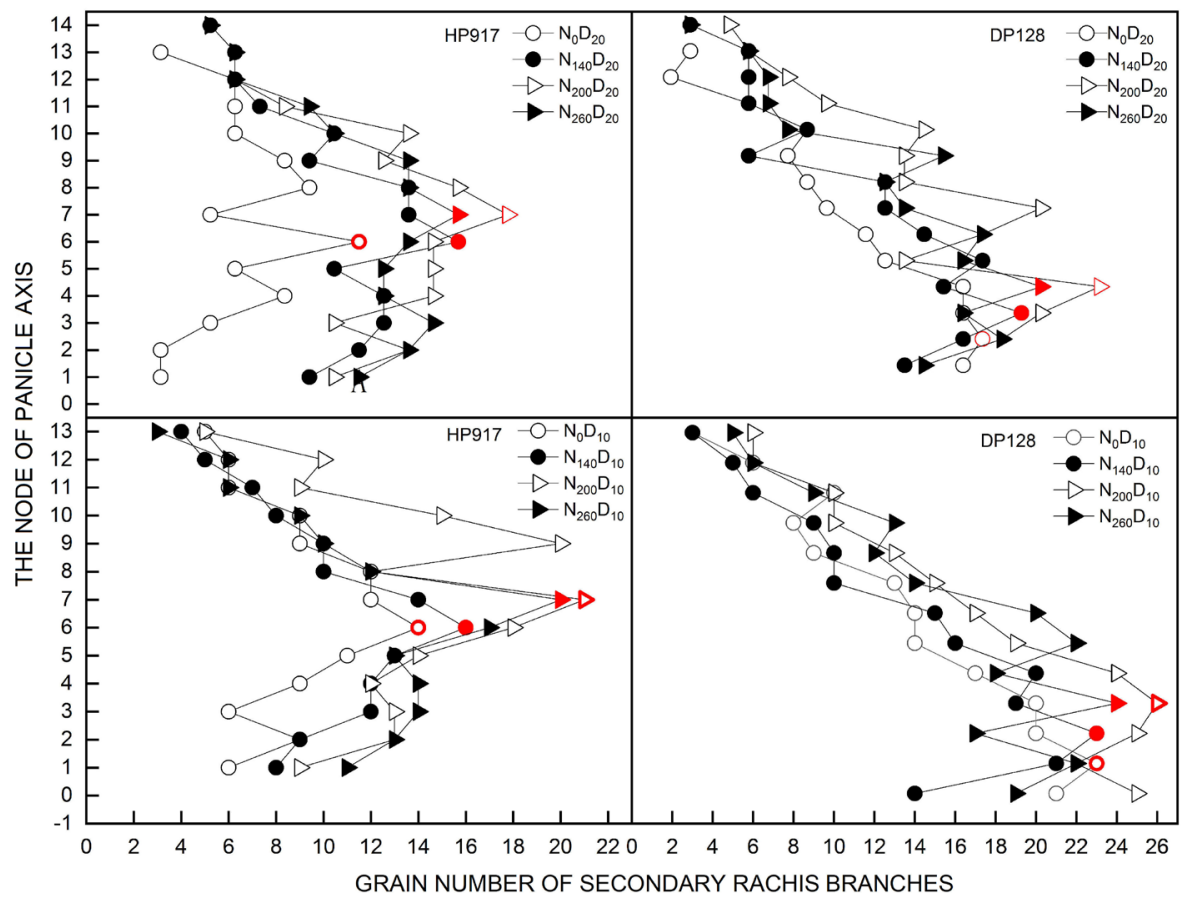

Fig. 2. Effect of the $\mathrm{N}$ rate and plant density on the grain number of secondary branches on the panicle axis in rice plants with different PTIs. Red represents the largest secondary branch grain number of primary branches on the panicle axis.

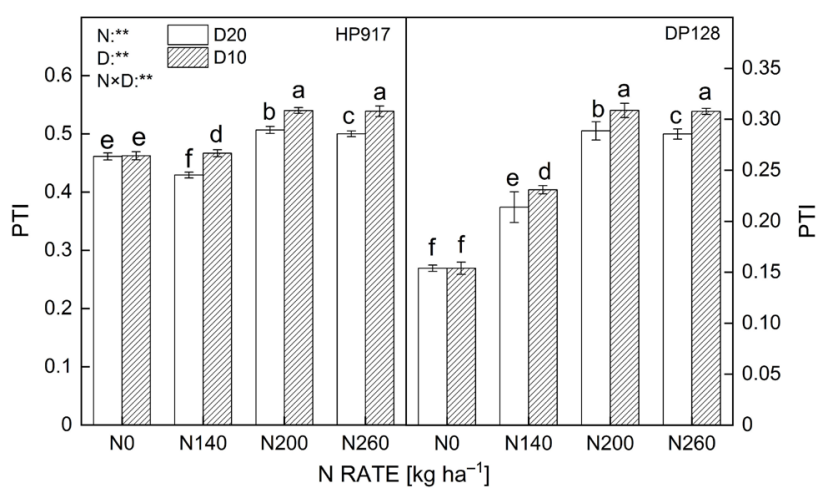

Fig. 3. Effect of the $\mathrm{N}$ rate and plant density on PTI in rice cultivars with different PTIs. $\mathrm{N}_{0}-0 \mathrm{~kg}(\mathrm{~N}) \mathrm{ha}^{-1} ; \mathrm{N}_{140}$ $140 \mathrm{~kg}(\mathrm{~N}) \mathrm{ha}^{-1} ; \mathrm{N}_{200}-200 \mathrm{~kg}(\mathrm{~N}) \mathrm{ha}^{-1} ;$ and $\mathrm{N}_{260}-260 \mathrm{~kg}(\mathrm{~N}) \mathrm{ha}^{-1}$. PTI represents the panicle trait index, and D represents the plant density, where $\mathrm{D}_{20}$ represents 15 plants $\mathrm{m}^{-2}$ and $\mathrm{D}_{10}$ represents 30 plants $\mathrm{m}^{-2}$.** indicates that the $\mathrm{N}$ application rate and plant density significantly influenced the PTI at the 0.01 level, and ns indicates 'nonsignificant'. Vertical bars represent the standard deviation. Different lowercase letters above the bars represent significant differences at the 0.05 level.

$260 \mathrm{~kg} \mathrm{ha}^{-1}$, the PTIs of HP917 and DP128 decreased from 0.52 and 0.30 to 0.51 and 0.29 (mean of two plant densities), respectively. Increasing the plant density from $D_{20}$ to $D_{10}$ resulted in an increase in the PTIs of HP917 and DP128 from 0.48 and 0.24 to 0.50 and 0.25 (mean of four $\mathrm{N}$ rates). The maximum PTI values appeared for HP917 and DP128 treated with the $\mathrm{N}$ fertilizer application rate of $200 \mathrm{~kg} \mathrm{ha}^{-1}$ and plant density of $\mathrm{D}_{10}$. Correlation analysis demonstrated that the PTI was positively correlated with F but negatively correlated with BFSB and BSB in HP917 plants (Fig. 4A). The PTI was positively correlated with GPP, MSB, and BSB but negatively correlated with $\mathrm{F}$ in DP128 plants (Fig. 4B).

Photosynthetic pigment: $\mathrm{N}$ rate, $\mathrm{N}$ rate and plant density interaction significantly affected the Chl content of HP917 and DP128 plants, but plant density had no significant effect on the Chl content, as shown in Table 3. The Chl contents of HP917 and DP128 plants increased from 1.22 and 1.57 to 2.17 and $2.09 \mathrm{mg} \mathrm{g}^{-1}$ (mean of two plant densities), respectively, as the $\mathrm{N}$ rate increased from 0 to $200 \mathrm{~kg} \mathrm{ha}^{-1}$, but decreased from 2.17 and 2.09 to 2.03 and $1.86 \mathrm{mg} \mathrm{g}^{-1}$ (mean of two plant densities), respectively, as the $\mathrm{N}$ rate increased from 200 to $260 \mathrm{~kg} \mathrm{ha}^{-1}$. Increasing the plant density from $\mathrm{D}_{20}$ to $\mathrm{D}_{10}$ resulted in an increase in the Chl contents of HP917 and DP128 from 1.75 and 1.78 to 1.85 and $1.86 \mathrm{mg} \mathrm{g}^{-1}$ (mean of four $\mathrm{N}$ rates), respectively. The maximum Chl contents of HP917 and DP128 plants appeared in the $200 \mathrm{~kg} \mathrm{ha}^{-1} \mathrm{~N}$ fertilizer and $\mathrm{D}_{10}$ plant density treatments.

Gas-exchange parameters: The $P_{\mathrm{N}}, E, g_{\mathrm{s}}, C_{\mathrm{i}}$, and $\mathrm{L}_{\mathrm{s}}$ values were significantly affected by $\mathrm{N}$ rate and plant density, but their interaction had a significant effect on only for $P_{\mathrm{N}}$ and $\mathrm{g}_{\mathrm{s}}$ in both the HP917 and DP128 cultivars (Table 3).

The $P_{\mathrm{N}}$ values of HP917 and DP128 increased from 18.98 and 16.34 to 22.17 and $21.40 \mu \mathrm{mol} \mathrm{m} \mathrm{m}^{-2} \mathrm{~s}^{-1}$ (mean of two plant densities), respectively, as the $\mathrm{N}$ rate increased from 0 to $200 \mathrm{~kg} \mathrm{ha}^{-1}$, but decreased from 22.17 and 21.40 to 21.28 and $18.98 \mu \mathrm{mol} \mathrm{m}^{-2} \mathrm{~s}^{-1}$ (mean of two plant densities), respectively, as the $\mathrm{N}$ rate increased from $200 \mathrm{~kg} \mathrm{ha}^{-1}$ to $260 \mathrm{~kg} \mathrm{ha}^{-1}$. Increasing the plant density from $\mathrm{D}_{20}$ to $\mathrm{D}_{10}$ resulted in an increase in the $P_{\mathrm{N}}$ values of HP917 and DP128 from 20.26 and 18.16 to 21.16 and 


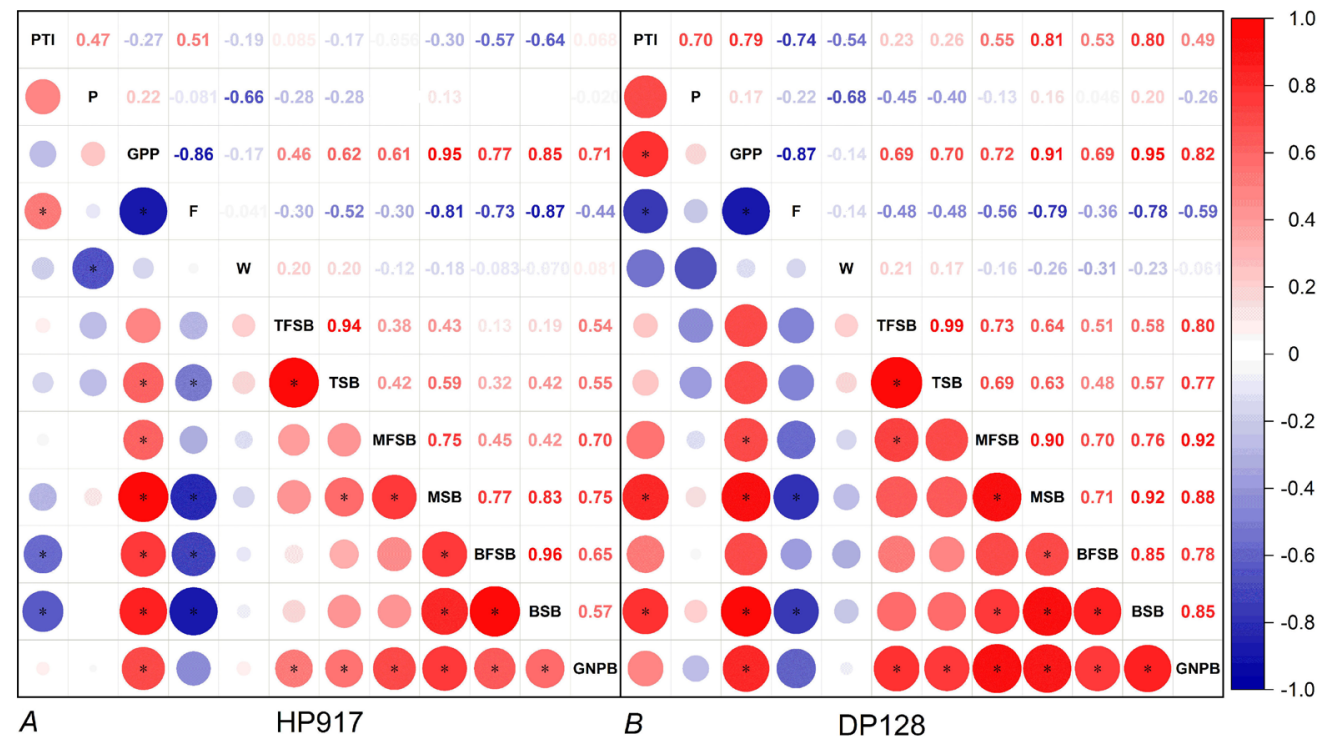

Fig. 4. Correlation analysis of yield components, panicle traits, and PTIs under the $\mathrm{N}$ rate and plant density interaction. $\mathrm{P}-$ panicle number per hectare, GPP - grain number per panicle, $\mathrm{F}$ - filled grain rate, $\mathrm{W}-1,000$-grain mass, TFSB - filled grain number of secondary branches of the top panicle, TSB - grain number of secondary branches of the top panicle, MFSB - filled grain number of secondary branches of the middle panicle, MSB - grain number of secondary branches of the middle panicle, BFSB - filled grain number of secondary branches of the bottom panicle, BSB - grain number of secondary branches of the bottom panicle, GNPB number of primary branches.

$18.96 \mu \mathrm{mol} \mathrm{m} \mathrm{m}^{-2} \mathrm{~s}^{-1}$ (mean of four $\mathrm{N}$ rates), respectively. The maximum values of $P_{\mathrm{N}}$ appeared at the $\mathrm{N}$ fertilization rate of $200 \mathrm{~kg} \mathrm{ha}^{-1}$ and a plant density of $\mathrm{D}_{10}$ for both HP917 and DP128.

The $g_{\mathrm{s}}$ values of HP917 and DP128 increased from 0.53 and 0.43 to 0.72 and $0.62 \mathrm{~mol} \mathrm{~m}^{-2} \mathrm{~s}^{-1}$ (mean of two plant densities), respectively, as the $\mathrm{N}$ rate increased from 0 to $200 \mathrm{~kg} \mathrm{ha}^{-1}$, but decreased from 0.72 and 0.62 to 0.69 and $0.60 \mathrm{~mol} \mathrm{~m}^{-2} \mathrm{~s}^{-1}$ (mean of two plant densities), respectively, as the $\mathrm{N}$ rate increased from 200 to $260 \mathrm{~kg} \mathrm{ha}^{-1}$. The $g_{\mathrm{s}}$ values of HP917 and DP128 increased from 0.62 and 0.53 to 0.67 and $0.57 \mathrm{~mol} \mathrm{~m}^{-2} \mathrm{~s}^{-1}$ (mean of four $\mathrm{N}$ rates), respectively, as the plant density increased from $\mathrm{D}_{20}$ to $\mathrm{D}_{10}$. The maximum values of $g_{\mathrm{s}}$ appeared at the $\mathrm{N}$ fertilization rate of $200 \mathrm{~kg} \mathrm{ha}^{-1}$ and plant density of $\mathrm{D}_{10}$ treatment for both HP917 and DP128.

As the $\mathrm{N}$ application rate increased from 0 to $200 \mathrm{~kg}$ $\mathrm{ha}^{-1}$, the $E$ of HP917 and DP128 increased from 7.06 and 5.97 to 10.31 and $6.81 \mathrm{mmol} \mathrm{m}^{-2} \mathrm{~s}^{-1}$ (mean of two plant densities), respectively. However, as the $\mathrm{N}$ rate increased from 200 to $260 \mathrm{~kg} \mathrm{ha}^{-1}$, the $E$ of HP917 and DP128 decreased from 10.31 and 6.81 to 9.86 and $6.3 \mathrm{mmol} \mathrm{m}^{-2} \mathrm{~s}^{-1}$ (mean of two plant densities), respectively. The $E$ of HP917 and DP128 increased from 8.7 and 5.77 to 9.12 and $8.7 \mathrm{mmol} \mathrm{m}^{-2} \mathrm{~s}^{-1}$ (mean of four $\mathrm{N}$ rates), respectively, as the plant density increased from $\mathrm{D}_{20}$ to $\mathrm{D}_{10}$. The maximum values of $E$ appeared for both HP917 and DP128 treated at the $\mathrm{N}$ fertilization rate of $200 \mathrm{~kg} \mathrm{ha}^{-1}$ and plant density of $\mathrm{D}_{10}$.

Increasing the $\mathrm{N}$ application rate from 0 to $200 \mathrm{~kg} \mathrm{ha}^{-1}$ resulted in a decrease in the $C_{\mathrm{i}}$ values of HP917 and DP128 from 164 and 141.9 to 150.5 and $125.8 \mu \mathrm{mol}$ $\mathrm{mol}^{-1}$ (mean of two plant densities), respectively, while increasing the $\mathrm{N}$ fertilizer rate from 200 to $260 \mathrm{~kg} \mathrm{ha}^{-1}$ resulted in an increase in the $C_{\mathrm{i}}$ values of HP917 and DP128 from 150.5 and $125.8 \mu \mathrm{mol} \mathrm{mol}^{-1}$ to 151.83 and $130 \mu \mathrm{mol} \mathrm{mol}{ }^{-1}$, respectively. The $C_{\mathrm{i}}$ values of HP917 and DP128 decreased from 156.9 and 132.6 to 153.2 and $131 \mu \mathrm{mol} \mathrm{mol} \mathrm{m}^{-1}$ (mean of four $\mathrm{N}$ rates), respectively, as the plant density increased from $\mathrm{D}_{20}$ to $\mathrm{D}_{10}$. The minimum values of $C_{\mathrm{i}}$ appeared at the $\mathrm{N}$ fertilizer rate of $200 \mathrm{~kg} \mathrm{ha}^{-1}$ and plant density of $\mathrm{D}_{10}$ for both HP917 and DP128.

As the $\mathrm{N}$ application rate increased from 0 to 200 $\mathrm{kg} \mathrm{ha}^{-1}$, the $\mathrm{L}_{\mathrm{s}}$ values of HP917 and DP128 increased from 0.28 and 0.28 to 0.46 and 0.41 (mean of two plant densities), respectively. However, as the $\mathrm{N}$ rate increased from 200 to $260 \mathrm{~kg} \mathrm{ha}^{-1}$, the $\mathrm{L}_{\mathrm{s}}$ values of HP917 and DP128 decreased from 0.46 and 0.41 to 0.41 and 0.38 (mean of two plant densities), respectively. The $\mathrm{L}_{\mathrm{s}}$ values of HP917 and DP128 increased from 1.44 and 0.97 to 1.60 and 1.51 (mean of four $\mathrm{N}$ rates), respectively, as the plant density increased from $\mathrm{D}_{20}$ to $\mathrm{D}_{10}$. The maximum $\mathrm{L}_{\mathrm{s}}$ values of HP917 and DP128 appeared at the $\mathrm{N}$ fertilization rate of $200 \mathrm{~kg} \mathrm{ha}^{-1}$ and plant density of $\mathrm{D}_{10}$ for both HP917 and DP128.

Relationship between the PTI and grain yield as well as $\boldsymbol{P}_{\mathrm{N}}$ : Correlation analysis demonstrated that the PTI was significantly and positively correlated with grain yield and $P_{\mathrm{N}}$ in rice with different PTIs (Fig. 5).

\section{Discussion}

The grain number of secondary branches on the panicle axis was closely related to yield, which was shown to 
Table 3. Effects of the $\mathrm{N}$ application rate and plant density on photosynthetic characteristics in rice with different PTIs. $P_{\mathrm{N}}$ represents the photosynthetic rate, $E$ represents the transpiration rate, $g_{\mathrm{s}}$ represents the stomatal conductance, and $C_{\mathrm{i}}$ represents the intercellular $\mathrm{CO}_{2}$ concentration. $\mathrm{L}_{\mathrm{s}}$ represents the stomatal limitation value. $\mathrm{N}_{0}-0 \mathrm{~kg}(\mathrm{~N}) \mathrm{ha}^{-1} ; \mathrm{N}_{140}-140 \mathrm{~kg}(\mathrm{~N}) \mathrm{ha}^{-1} ; \mathrm{N}_{200}-200 \mathrm{~kg}(\mathrm{~N}) \mathrm{ha}^{-1} ;$ and $\mathrm{N}_{260}-$ $260 \mathrm{~kg}(\mathrm{~N}) \mathrm{ha}^{-1}$. D represents the plant density, where $\mathrm{D}_{20}$ represents 15 plants $\mathrm{m}^{-2}$ and $\mathrm{D}_{10}$ represents 30 plants $\mathrm{m}^{-2}$. Data are represented as the mean $\pm \mathrm{SD}$ of triplicates. $*$ and $* *$ indicate significant differences at the $5 \%$ and $1 \%$ levels, respectively, and ns indicates 'nonsignificant'. Values of the eight treatments followed by different lowercase letters indicate a significant difference at the $5 \%$ level.

\begin{tabular}{|c|c|c|c|c|c|c|c|c|}
\hline \multirow{2}{*}{$\begin{array}{l}\text { Variety } \\
\text { HP917 }\end{array}$} & \multicolumn{2}{|c|}{ Treatments } & \multirow{2}{*}{$\begin{array}{l}P_{\mathrm{N}} \\
\frac{\left[\mu \mathrm{mol} \mathrm{m}{ }^{-2} \mathrm{~s}^{-1}\right]}{18.25 \pm 0.52^{\mathrm{d}}}\end{array}$} & \multirow{2}{*}{$\begin{array}{l}g_{\mathrm{s}} \\
{\left[\mathrm{mol} \mathrm{m}^{-2} \mathrm{~s}^{-1}\right]} \\
0.51 \pm 0.02^{\mathrm{f}}\end{array}$} & \multirow{2}{*}{$\begin{array}{l}C_{\mathrm{i}} \\
{\left[\mu \mathrm{mol} \mathrm{mol}^{-1}\right]} \\
160.67 \pm 4.04^{\mathrm{b}}\end{array}$} & \multirow{2}{*}{$\begin{array}{l}E \\
{\left[\begin{array}{l}\left.\mathrm{mmol} \mathrm{m}^{-2} \mathrm{~s}^{-1}\right] \\
6.88 \pm 0.97^{\mathrm{f}}\end{array}\right.}\end{array}$} & \multirow{2}{*}{$\begin{array}{l}\mathrm{L}_{\mathrm{s}} \\
0.27 \pm 0.04^{\mathrm{e}}\end{array}$} & \multirow{2}{*}{$\begin{array}{l}\text { Chl } \\
{\left[\mathrm{mg} \mathrm{g}^{-1}(\mathrm{FM})\right]} \\
1.13 \pm 0.10^{\mathrm{e}}\end{array}$} \\
\hline & $\mathrm{N}_{0}$ & $\mathrm{D}_{20}$ & & & & & & \\
\hline & & $\mathrm{D}_{10}$ & $19.70 \pm 0.10^{c}$ & $0.55 \pm 0.03^{\mathrm{e}}$ & $167.33 \pm 9.07^{\mathrm{a}}$ & $7.24 \pm 0.18^{\mathrm{e}}$ & $0.29 \pm 0.03^{\mathrm{e}}$ & $1.30 \pm 0.05^{\mathrm{d}}$ \\
\hline & $\mathrm{N}_{140}$ & $\mathrm{D}_{20}$ & $19.73 \pm 0.41^{\mathrm{c}}$ & $0.63 \pm 0.03^{\mathrm{d}}$ & $155.33 \pm 1.57^{\mathrm{c}}$ & $8.20 \pm 0.10^{\mathrm{d}}$ & $0.36 \pm 0.02^{\mathrm{c}}$ & $1.75 \pm 0.24^{\mathrm{c}}$ \\
\hline & & $\mathrm{D}_{10}$ & $21.10 \pm 0.41^{\mathrm{b}}$ & $0.64 \pm 0.02^{\mathrm{d}}$ & $149.33 \pm 2.52^{\mathrm{d}}$ & $8.60 \pm 0.10^{c}$ & $0.39 \pm 0.02^{\mathrm{bc}}$ & $1.83 \pm 0.05^{\mathrm{c}}$ \\
\hline & $\mathrm{N}_{200}$ & $\mathrm{D}_{20}$ & $21.57 \pm 0.55^{b}$ & $0.68 \pm 0.01^{\mathrm{c}}$ & $157.33 \pm 5.51^{b c}$ & $9.97 \pm 0.10^{b}$ & $0.45 \pm 0.01^{\mathrm{ab}}$ & $2.10 \pm 0.03^{\mathrm{ab}}$ \\
\hline & & $\mathrm{D}_{10}$ & $22.77 \pm 0.21^{\mathrm{a}}$ & $0.76 \pm 0.02^{\mathrm{a}}$ & $146.67 \pm 1.15^{\mathrm{d}}$ & $10.65 \pm 0.53^{\mathrm{a}}$ & $0.46 \pm 0.02^{\mathrm{a}}$ & $2.23 \pm 0.07^{\mathrm{a}}$ \\
\hline & $\mathrm{N}_{260}$ & $\mathrm{D}_{20}$ & $21.10 \pm 0.46^{\mathrm{b}}$ & $0.67 \pm 0.02^{\mathrm{c}}$ & $154.33 \pm 3.79^{c}$ & $9.73 \pm 0.19^{b}$ & $0.36 \pm 0.03^{\mathrm{cd}}$ & $2.01 \pm 0.09^{b}$ \\
\hline & & $\mathrm{D}_{10}$ & $21.45 \pm 0.82^{\mathrm{b}}$ & $0.72 \pm 0.02^{b}$ & $149.33 \pm 0.57^{\mathrm{d}}$ & $9.98 \pm 0.17^{b}$ & $0.46 \pm 0.01^{\mathrm{a}}$ & $2.05 \pm 0.13^{b}$ \\
\hline \multirow[t]{8}{*}{ DP128 } & $\mathrm{N}_{0}$ & $\mathrm{D}_{20}$ & $16.31 \pm 0.22^{\mathrm{f}}$ & $0.41 \pm 0.02^{\mathrm{f}}$ & $140.00 \pm 2.65^{\mathrm{a}}$ & $5.43 \pm 0.03^{\mathrm{d}}$ & $0.25 \pm 0.06^{\mathrm{d}}$ & $1.43 \pm 0.06^{\mathrm{e}}$ \\
\hline & & $\mathrm{D}_{10}$ & $16.36 \pm 0.16^{\mathrm{f}}$ & $0.45 \pm 0.03^{\mathrm{e}}$ & $143.67 \pm 5.86^{\mathrm{a}}$ & $6.51 \pm 0.04^{b}$ & $0.31 \pm 0.05^{\mathrm{cd}}$ & $1.70 \pm 0.07^{\mathrm{d}}$ \\
\hline & $\mathrm{N}_{140}$ & $\mathrm{D}_{20}$ & $17.10 \pm 0.20^{\mathrm{e}}$ & $0.53 \pm 0.03^{\mathrm{d}}$ & $124.33 \pm 2.08^{c}$ & $5.55 \pm 0.02^{\mathrm{d}}$ & $0.31 \pm 0.04^{\mathrm{cd}}$ & $1.71 \pm 0.22^{\mathrm{d}}$ \\
\hline & & $\mathrm{D}_{10}$ & $18.12 \pm 0.25^{\mathrm{d}}$ & $0.54 \pm 0.02^{\mathrm{d}}$ & $134.67 \pm 2.52^{\mathrm{b}}$ & $6.77 \pm 0.02^{\mathrm{b}}$ & $0.33 \pm 0.08^{\mathrm{bc}}$ & $1.81 \pm 0.17^{\mathrm{cd}}$ \\
\hline & $\mathrm{N}_{200}$ & $\mathrm{D}_{20}$ & $20.98 \pm 0.40^{\mathrm{b}}$ & $0.59 \pm 0.02^{\mathrm{c}}$ & $131.00 \pm 2.64^{b}$ & $6.10 \pm 0.10^{c}$ & $0.38 \pm 0.03^{\mathrm{ab}}$ & $2.05 \pm 0.04^{\mathrm{ab}}$ \\
\hline & & $\mathrm{D}_{10}$ & $21.81 \pm 0.30^{\mathrm{a}}$ & $0.65 \pm 0.01^{\mathrm{a}}$ & $120.67 \pm 3.79^{c}$ & $7.51 \pm 0.04^{\mathrm{a}}$ & $0.44 \pm 0.14^{\mathrm{a}}$ & $2.13 \pm 0.07^{\mathrm{a}}$ \\
\hline & $\mathrm{N}_{260}$ & $\mathrm{D}_{20}$ & $18.40 \pm 0.50^{\mathrm{d}}$ & $0.57 \pm 0.01^{\mathrm{c}}$ & $135.00 \pm 4.00^{\mathrm{b}}$ & $6.00 \pm 0.20^{\mathrm{c}}$ & $0.32 \pm 0.01^{\mathrm{bcd}}$ & $1.93 \pm 0.20^{\mathrm{bc}}$ \\
\hline & & $\mathrm{D}_{10}$ & $19.56 \pm 0.60^{\mathrm{c}}$ & $0.62 \pm 0.02^{\mathrm{b}}$ & $125.00 \pm 1.00^{\mathrm{c}}$ & $6.67 \pm 0.15^{\mathrm{b}}$ & $0.43 \pm 0.08^{\mathrm{a}}$ & $1.79 \pm 0.06^{\mathrm{cd}}$ \\
\hline \multirow[t]{7}{*}{ ANOVA } & \multicolumn{2}{|c|}{$\mathrm{N}$ level $(\mathrm{N})$} & $* *$ & $* *$ & $* *$ & $* *$ & $* *$ & $* *$ \\
\hline & \multicolumn{2}{|c|}{ Density (D) } & $* *$ & $* *$ & $* *$ & $* *$ & $* *$ & $*$ \\
\hline & \multicolumn{2}{|c|}{ Variety (V) } & $* *$ & $* *$ & $* *$ & $* *$ & $* *$ & $\mathrm{~ns}$ \\
\hline & \multicolumn{2}{|c|}{$\mathrm{V} \times \mathrm{N}$} & $* *$ & ns & $* *$ & $* *$ & $\mathrm{~ns}$ & $* *$ \\
\hline & \multicolumn{2}{|c|}{$\mathrm{V} \times \mathrm{D}$} & ns & $\mathrm{ns}$ & $\mathrm{ns}$ & $* *$ & ns & ns \\
\hline & \multicolumn{2}{|c|}{$\mathrm{N} \times \mathrm{D}$} & $* *$ & $*$ & ns & $\mathrm{ns}$ & ns & $*$ \\
\hline & \multicolumn{2}{|c|}{$\mathrm{V} \times \mathrm{N} \times \mathrm{D}$} & ns & ns & $\mathrm{ns}$ & ns & ns & $\mathrm{ns}$ \\
\hline
\end{tabular}

be mainly controlled by heredity (Sasahara et al. 1982). According to the 'Sasahara index', indica rice is a superior dominant type, japonica rice is a middle dominant type, and javanica rice is an inferior dominant type (Sasahara et al. 1982). Xu et al. (2005) found that a relatively high PTI was beneficial to improving yield and $\mathrm{Xu}$ et al. (2010) reported that PTI was significantly influenced by the environment in two recombinant inbred line (RIL) populations, with a significant decrease in PTI from Liaoning to Sichuan Province in China. However, few studies have paid attention to the effects of the $\mathrm{N}$ rate and plant density interaction on PTI. In the present study, the $\mathrm{N}$ rate and plant density interaction significantly affected the GNSB of the middle and bottom panicles in rice with different PTIs, which, in turn, influenced the PTI (Table 1, Figs. 2 and 3). Compared with $\mathrm{N}_{0}, \mathrm{~N}_{140}$ affected the PTI by increasing the number of primary branches of different PTI rice plants in the $\mathrm{D}_{20}$ group, and other treatments affected the PTI by moving up the largest secondary branch GNPB on the node of the panicle axis of rice plants with different PTIs. With an increasing $\mathrm{N}$ rate, the PTI significantly increased at first and then plateaued or decreased at both plant densities. The PTI increased with increasing plant density from $\mathrm{D}_{20}$ to $\mathrm{D}_{10}$ in rice with different PTIs at the four $\mathrm{N}$ rates. There are few published studies in this field. Thus, it is necessary to further study how the grain distribution of secondary branches on the panicle axis affects the grain yield.

Photosynthetic capacity is the basis of crop growth and development and is used to determine the composition of crop productivity (Richards 2000). The photosynthetic capacity of a single leaf is directly indicated by $P_{\mathrm{N}}$ (Jiang et al. 2004). E, $C_{\mathrm{i}}, g_{s}, \mathrm{~L}_{\mathrm{s}}$, and Chl content are vital indices used to describe the photosynthesis of plants and have close relationships with $P_{\mathrm{N}}$ (Liu et al. 2010). Previous studies have shown that photosynthetic capacity has a positive correlation with the $\mathrm{N}$ rate (Ripullone et al. 2003, Belane and Dakora 2011), but once it is above critical maxima, $\mathrm{N}$ can potentially deactivate the photosynthetic machinery (Cheng and Fuchigami 2000). Similarly, in our study, the leaf photosynthetic capacity increased with the increase of the $\mathrm{N}$ rate from 0 to $200 \mathrm{~kg} \mathrm{ha}^{-1}$. However, the leaf photosynthetic capacity decreased with the increase of the $\mathrm{N}$ rate from 200 to $260 \mathrm{~kg} \mathrm{ha}^{-1}$ in rice with different PTIs at both plant densities. Two reasons could be responsible for the decrease of leaf photosynthetic capacity. The first 


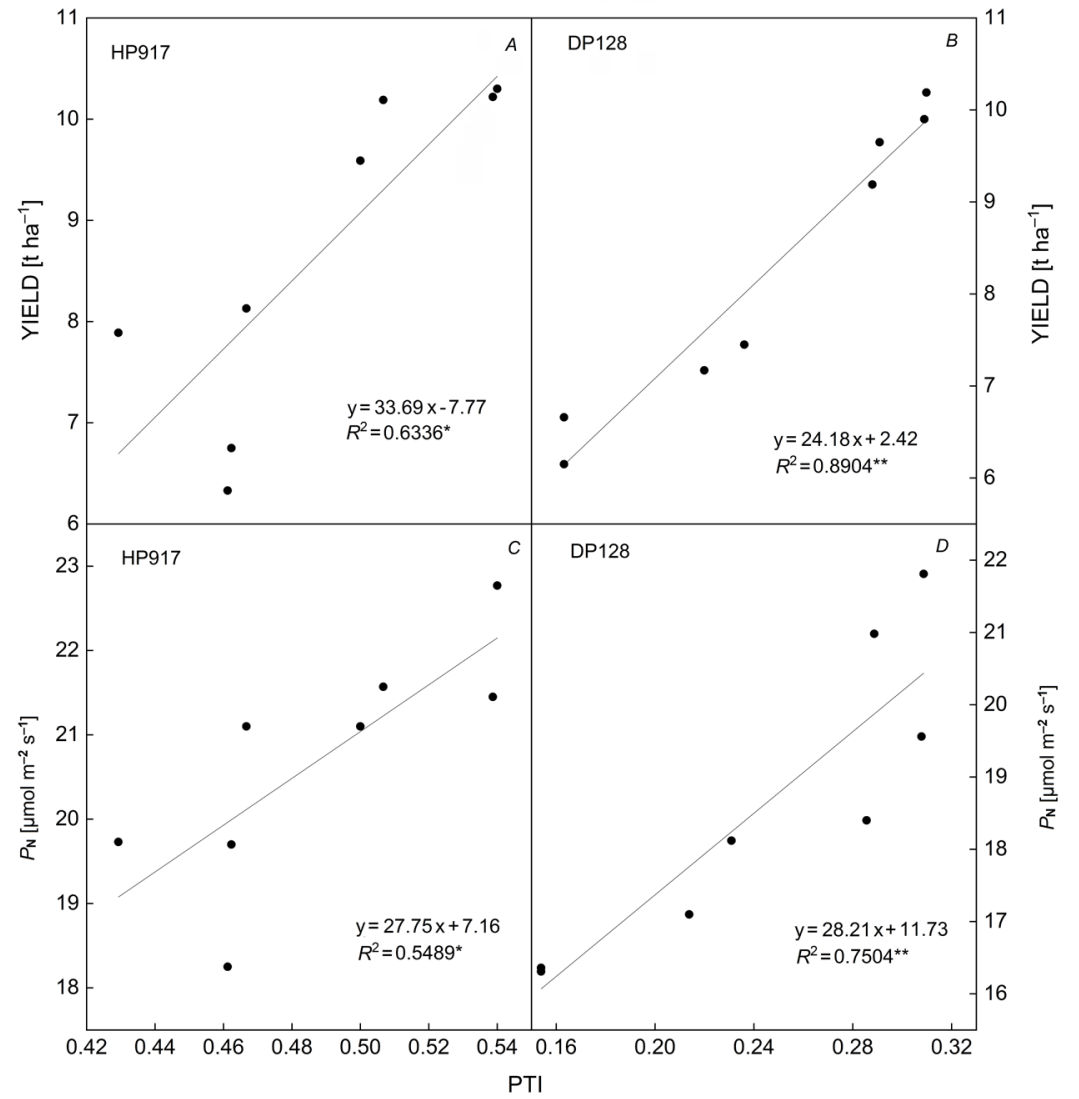

Fig. 5. Relationships between the panicle trait index (PTI) and grain yield and between the PTI and net photosynthetic rate $\left(P_{\mathrm{N}}\right)$ in rice with different PTIs. * and ** indicate significant correlations at the $5 \%$ and $1 \%$ levels, respectively. is the weak light irradiance to the leaf due to shading and because of the excessive $\mathrm{N}$ rate promoting leaf development. The second is that rice grew excessively tall at the higher $\mathrm{N}$ rate and became susceptible to lodging. The increase of $\mathrm{L}_{\mathrm{s}}$ and decrease of $C_{\mathrm{i}}$ indicates that the decline of stomatal conductance was responsible for the decrease of $P_{\mathrm{N}}$, while the decrease of $\mathrm{L}_{\mathrm{s}}$ and increase of $C_{\mathrm{i}}$ implies that the reduction of photosynthetic activity of mesophyll cells could account for the decrease of $P_{\mathrm{N}}$ (Farquhar and Sharkey 1982, Liu et al. 2010). In the present study, the $\mathrm{N}$ rate significantly affected the $P_{\mathrm{N}}, C_{\mathrm{i}}$, and $\mathrm{L}_{\mathrm{s}}$ of leaf in rice with different PTIs, and $\mathrm{N}$ deficiency $\left(0 \mathrm{~kg} \mathrm{ha}^{-1}\right)$ increased $C_{\mathrm{i}}$, and reduced $P_{\mathrm{N}}$ and $\mathrm{L}_{\mathrm{s}}$. These results imply that the $\mathrm{N}$ rate increased the $P_{\mathrm{N}}$ mainly by nonstomatal factors, such as the increase of photosynthetic activity of mesophyll cells. Plant density is an important factor coordinating the contradiction between crop individuals and populations (Wang et al. 2009). Low plant density resulted in declines of $P_{\mathrm{N}}$ and $\mathrm{L}_{\mathrm{s}}$ and an increase of $C_{\mathrm{i}}$ (Fang et al. 2018). Similar to our study, increasing the plant density from $\mathrm{D}_{20}$ to $\mathrm{D}_{10}$ resulted in increased $P_{\mathrm{N}}$ and $\mathrm{L}_{\mathrm{s}}$, and declined $C_{\mathrm{i}}$. Regression analysis suggested that the PTI was positively correlated with $P_{\mathrm{N}}$.

Many studies have focused on the effects of $\mathrm{N}$ application rate or plant density on the grain yield and the yield components of rice (Sun et al. 2012, Huang et al. 2013, Ahmed et al. 2016, Hou et al. 2019). N application is vital for grain yield (Mahajan et al. 2011). The grain yield significantly increased when the application rate of
$\mathrm{N}$ fertilizer reached a certain level. However, a further increase in $\mathrm{N}$ could lead to a decrease in grain yield. Many studies have reported a decrease in grain yield under excessive $\mathrm{N}$ application (Fan et al. 2005, Jing et al. 2007, Zhang et al. 2009a,b). The present study confirmed the results of previous studies and showed that the $\mathrm{N}$ rate and plant density interaction had significant effects on the grain yield and the yield components of rice with different PTIs (Table 3). With increasing $\mathrm{N}$ application rate, the grain yield of rice with different PTIs significantly increased at first and then decreased at both plant densities. Compared with that of the $D_{20}$ group, the grain yield of the $D_{10}$ group was higher. Hou et al. (2019) showed that increasing the plant density appropriately is an effective way to improve the grain yield of rice. $\mathrm{N}_{200}$ combined with $\mathrm{D}_{10}$ treatment was optimal for yield formation among all the treatments. Regression analysis suggested that the PTI was significantly and positively correlated with grain yield.

The $\mathrm{N}$ application rate and plant density are two vital factors affecting yield components (Huang et al. 2011, Hou et al. 2019). In this study, the $\mathrm{N}$ rate and the plant density significantly affected the panicle number per hill, the spikelet number per panicle, and $\mathrm{F}$, which has also been found in previous studies (Hou et al. 2019). With a constant $\mathrm{N}$ rate, the $\mathrm{F}$ of the $\mathrm{D}_{20}$ group was lower than that of the $\mathrm{D}_{10}$ group due to $\mathrm{N}$ deficiency.

Conclusions: The $\mathrm{N}$ rate and plant density interaction increased the number of primary branches and the GNSB of 
the middle and bottom panicles, which, in turn, influenced the PTI of the rice plants. With an increase in the $\mathrm{N}$ rate, the PTI significantly increased at first and then plateaued or decreased. Increasing the plant density from $\mathrm{D}_{20}$ to $\mathrm{D}_{10}$ significantly increased the PTI. An appropriate $\mathrm{N}$ rate and plant density could improve the PTI from the bottom to middle panicle axes. $\mathrm{N}$ fertilization and plant density also had significant effects on leaf capacity and grain yield. The leaf capacity and grain yield first increased and then decreased with increasing $\mathrm{N}$ fertilization. Regression analysis suggested that the PTI was positively correlated with grain yield as well as $P_{\mathrm{N}}$. These results further indicated that the improvement in the PTI from 0.15 to 0.52 is beneficial to increase the grain yield, which might contribute to the increased grain number of secondary branches of the middle and bottom panicle.

\section{References}

Ahmed S., Humphreys E., Salim M., Chauhan B.S.: Growth, yield and nitrogen use efficiency of dry-seeded rice as influenced by nitrogen and seed rates in Bangladesh. - Field Crop. Res. 186: 18-31, 2016.

Belane A.K., Dakora F.D.: Photosynthesis, symbiotic N and C accumulation in leaves of 30 nodulated cowpea genotypes grown in the field at Wa in the Guinea savanna of Ghana. Field Crop. Res. 124: 279-287, 2011.

Berry P.M., Spink J., Foulkes M.J., White P.J.: The physiological basis of genotypic differences in nitrogen use efficiency in oilseed rape (Brassica napus L.). - Field Crop. Res. 119: 365373, 2010.

Cheng L., Fuchigami L.H.: Rubisco activation state decreases with increasing nitrogen content in apple leaves. - J. Exp. Bot. 51: 1687-1694, 2000

Di Salvo L.P., Cellucci G.C., Carlino M.E., de Salamone I.E.G.: Plant growth-promoting rhizobacteria inoculation and nitrogen fertilization increase maize (Zea mays L.) grain yield and modified rhizosphere microbial communities. - Appl. Soil Ecol. 126: 113-120, 2018.

Dordas C.A., Sioulas C.: Safflower yield, chlorophyll content, photosynthesis, and water use efficiency response to nitrogen fertilization under rainfed conditions. - Ind. Crop. Prod. 27: $75-85,2008$

Fan M., Jiang R., Liu X. et al.: Interactions between non-flooded mulching cultivation and varying nitrogen inputs in ricewheat rotations. - Field Crop. Res. 91: 307-318, 2005.

Fang X.M., Li Y.S., Nie J. et al.: Effects of nitrogen fertilizer and planting density on the leaf photosynthetic characteristics, agronomic traits and grain yield in common buckwheat (Fagopyrum esculentum M.). - Field Crop. Res. 219: 160168,2018

Farquhar G.D., Sharkey T.D.: Stomatal conductance and photosynthesis. - Ann. Rev. Plant Physio. 33: 317-345, 1982.

Fischer R.A.: Wheat physiology: a review of recent developments. - Crop Pasture Sci. 62: 95-114, 2011.

Fitzgerald M.A., McCouch S.R., Hall R.D.: Not just a grain of rice: the quest for quality. - Trends Plant Sci. 14: 133-139, 2009.

Hou W.F., Khan M.R., Zhang J.L. et al.: Nitrogen rate and plant density interaction enhances radiation interception, yield and nitrogen use efficiency of mechanically transplanted rice. Agr. Ecosyst. Environ. 269: 183-192, 2019.

Hua J.P., Xing Y.Z., Xu C.G. et al.: Genetic dissection of an elite rice hybrid revealed that heterozygotes are not always advantageous for performance. - Genetics 162: 1885-1895, 2002.

Huang M., Yang C.L., Ji Q.M. et al.: Tillering responses of rice to plant density and nitrogen rate in a subtropical environment of southern China. - Field Crop. Res. 149: 187-192, 2013.

Huang M., Zou Y.B., Jiang P. et al.: Yield component differences between direct-seeded and transplanted super hybrid rice. Plant Prod. Sci. 14: 331-338, 2011.

Jiang D., Dai T., Jing Q. et al.: Effects of long-term fertilization on leaf photosynthetic characteristics and grain yield in winter wheat. - Photosynthetica 42: 439-446, 2004.

Jin J.Y., He P.: [Effect of $\mathrm{N}$ and $\mathrm{K}$ nutrition on post metabolism of carbon and nitrogen and grain weight formation in maize.] - Sci. Agr. Sin. 122: 567-577, 1999. [In Chinese]

Jing Q., Bouman B.A.M., Hengsdijk H. et al.: Exploring options to combine high yields with high nitrogen use efficiencies in irrigated rice in China. - Eur. J. Agron. 26: 166-177, 2007.

Jones D.B., Snyder G.H.: Seeding rate and row spacing effects on yield and yield components of ratoon rice. - Agron. J. 79: 627-629, 1987.

Kato T., Shinmura D., Taniguchi A.: Activities of enzymes for sucrose-starch conversion in developing endosperm of rice and their association with grain filling in extra-heavy panicle types. - Plant Prod. Sci. 10: 442-450, 2007.

Kuroda E., Abe S., Ishibashi F. et al.: [Varietal difference in the relationship between the number of panicles per hill and the number of spikelets per panicle on the main stems and on primary and secondary tillers of rice.] - Jpn. J. Crop. Sci. 68: 385-389, 1999. [In Japanese]

Li Y., Yang X.X., Ren B.B. et al.: Why nitrogen use efficiency decreases under high nitrogen supply in rice (Oryza sativa L.) seedlings. - J. Plant Growth Regul. 31: 47-52, 2012.

Lichtenthaler H.K.: Chlorophylls and carotenoids: pigments of photosynthetic biomembranes. - Method. Enzymol. 148: 350-382, 1987.

Liu H.G., Hu C.X., Sun X.C. et al.: Interactive effects of molybdenum and phosphorus fertilizers on photosynthetic characteristics of seedlings and grain yield of Brassica napus. - Plant Soil 326: 345-353, 2010.

Liu X., Wei X., Sheng Z. et al.: Polycomb protein OsFIE2 affects plant height and grain yield in rice. - PLoS ONE 11: e0164748, 2016.

Mahajan G., Chauhan B.S., Gill M.S.: Optimal nitrogen fertilization timing and rate in dry-seeded rice in northwest India. - Agron. J. 103: 1676-1682, 2011.

Mu X.H., Chen Q.W., Chen F.J. et al.: Within-leaf nitrogen allocation in adaptation to low nitrogen supply in maize during grain-filling stage. - Front. Plant Sci. 7: 699, 2016.

Muthayya S., Sugimoto J.D., Montgomery S., Maberly G.F.: An overview of global rice production, supply, trade, and consumption. - Ann. N.Y. Acad. Sci. 1324: 7-14, 2014.

Peng S., Khush G.S., Virk P. et al.: Progress in ideotype breeding to increase rice yield potential. - Field Crop. Res. 108: 32-38, 2008.

Richards R.A.: Selectable traits to increase crop photosynthesis and yield of grain crops. - J. Exp. Bot. 51: 447-458, 2000.

Ripullone F., Grassi G., Lauteri M., Borghetti M.: Photosynthesisnitrogen relationships: interpretation of different patterns between Pseudotsuga menziesii and Populus $\times$ euroamericana in a mini-stand experiment. - Tree Physiol. 23: 137-144, 2003.

Sage R.F., Pearcy R.W.: The nitrogen use efficiency of $\mathrm{C}_{3}$ and $\mathrm{C}_{4}$ plants: II. Leaf nitrogen effects on the gas exchange characteristics of Chenopodium album (L.) and Amaranthus retroflexus (L.). - Plant Physiol. 84: 959-963, 1987.

Sasahara T.K., Kodama K.I., Kambayashi M.H.K.: [Studies on structure and function on the rice ear.] - Jpn. J. Crop. Sci. 51: 
26-34, 1982. [In Japanese]

Seck P.A., Diagne A., Mohanty S., Wopereis M.C.S.: Crops that feed the world 7: Rice. - Food Secur. 4: 7-24, 2012.

Sekhar S., Gharat S.A., Panda B.B. et al.: Identification and characterization of differentially expressed genes in inferior and superior spikelets of rice cultivars with contrasting panicle-compactness and grain-filling properties. - PLoS ONE 10: e0145749, 2015.

Shangguan Z., Shao M., Dyckmans J.: Effects of nitrogen nutrition and water deficit on net photosynthetic rate and chlorophyll fluorescence in winter wheat. - J. Plant Physiol. 156: 46-51, 2000.

Sheehy J.E., Dionora M.J.A., Mitchell P.L.: Spikelet numbers, sink size and potential yield in rice. - Field Crop. Res. 71: $77-85,2001$.

Shiratsuchi H., Ohdaira Y., Takanashi J.: Relationship between dry weight at heading and the number of spikelets on individual rice tillers. - Plant Prod. Sci. 10: 430-441, 2007.

Steer B.T., Harrigan E.K.S.: Rates of nitrogen supply during different developmental stages affect yield components of safflower (Carthamus tinctorius L.). - Field Crop. Res. 14: 221-231, 1986.

Sun Y.J., Ma J., Sun Y.Y. et al.: The effects of different water and nitrogen managements on yield and nitrogen use efficiency in hybrid rice of China. - Field Crop. Res. 127: 85-98, 2012.

Veronica N., Subrahmanyam D., Kiran T.V. et al.: Influence of low phosphorus concentration on leaf photosynthetic characteristics and antioxidant response of rice genotypes. Photosynthetica 55: 285-293, 2017.

Wang D., Lu Q., Li X.F. et al.: Relationship between Rubisco activase isoform levels and photosynthetic rate in different leaf positions of rice plant. - Photosynthetica 47: 621-629, 2009.

Wang J., Xu H.X., Li N.W. et al.: Artificial selection of gnla plays an important role in improving rice yields across different ecological regions. - Rice 8: 37, 2015.

Wells B.R., Faw W.F.: Short-statured rice response to seeding and $\mathrm{N}$ rates. - Agron. J. 70: 477-480, 1978.

Xu H., Zhu C.J., Guo Y.H. et al.: Relationship of panicle type index and subspecies characteristics, yield traits in filial generations of cross between indica and japonica rice. - Rice Sci. 17: 149-155, 2010.

Xu Z.J., Chen W.F., Zhang S.L. et al.: [Differences of panicle trait index among varieties and its relationship with yield and quality of rice in Liaoning.] - Sci. Agr. Sin. 38: 1926-1930, 2005. [In Chinese]

Yamano T., Arouna A., Labarta R.A. et al.: Adoption and impacts of international rice research technologies. - Glob. Food Secur. 8: 1-8, 2016.

Yang J.C, Zhang J.H.: Grain-filling problem in 'super' rice. J. Exp. Bot. 61: 1-5, 2010.

Yao Y., Yamamoto Y., Wang Y. et al.: Numbers of degenerated and surviving spikelets associated with the number of differentiated spikelets among various rice cultivars. - Jpn. J. Trop. Agr. 44: 51-60, 2000.

Zhang R.D., Zhou Y.F., Yue Z.X. et al:: Changes in photosynthesis, chloroplast ultrastructure, and antioxidant metabolism in leaves of sorghum under waterlogging stress. Photosynthetica 57: 1076-1083, 2019.

Zhang Y.B., Tang Q.Y., Zou Y.B. et al.: Yield potential and radiation use efficiency of 'super' hybrid rice grown under subtropical conditions. - Field Crop. Res. 114: 91-98, 2009b.

Zhang Y.L., Fan J.B., Wang D.S., Shen Q.R.: Genotypic differences in grain yield and physiological nitrogen use efficiency among rice cultivars. - Pedosphere 6: 681-691, 2009a.

Zhao X., Xie Y.X., Xiong Z.Q. et al.: Nitrogen fate and environmental consequence in paddy soil under rice-wheat rotation in the Taihu lake region, China. - Plant Soil 319 : 225-234, 2009.

(C) The authors. This is an open access article distributed under the terms of the Creative Commons BY-NC-ND Licence. 